\title{
periferio
}

\section{RESILIENT EDUCATIONAL LEADERS IN TURBULENT TIMES: APPLYING THE LEADER RESILIENCE PROFILE ® TO ASSESS RESILIENCY IN RELATIONSHIP TO GENDER AND AGE}

\author{
Diane E. Reed ${ }^{1}$ \\ St. John Fisher College
}

\begin{abstract}
Women leaders across the world confront a common challenge: extremely turbulent times that challenge even the most skillful leaders. The paper begins with a brief overview of the meaning of leader resilience and describes the resilience cycle that all leaders experience when adversity strikes. Five phases of the resilience cycle discussed are: normal conditions, deteriorating phase, adapting phase, recovering phase and growing phase. Next, the paper traces the development of the revised Leader Resilience Profile ${ }^{\circledR}$ (LRP) data that compares and contrasts leader resilience by gender and age. The results clearly show that resilience increased reliably with age. Participants in the $60+$ age group, compared with the all-other age groups combined, had significantly higher resilience scores. In the 20-29 age group men had significant higher resilience than women. There were no reliable gender differences in resilience in the other age categories. The findings are based on a relatively small sample. Further research should be conducted on larger samples in each age range. The paper concludes by addressing two issues: How can the LRP be used across countries to assess women leader resilience and how can the LRP be applied to develop professional growth opportunities to strengthen women leaders' resilience.
\end{abstract}

Keywords: educational leaders; resilience; gender; age

\footnotetext{
${ }^{1}$ Doctor and Master in Education (EdD) - University of Rochester. Diane E. Reed, Educational Leadership Program, St. John Fisher College. [B. Evan Blaine, Statistics and Data Sciences Program, St. John Fisher College, assisted with the data analysis.] Correspondence concerning this article should be addressed to Diane E. Reed, Educational Leadership Program, St. John Fisher College, 3690 East Avenue, Rochester, New York 14618. Email: dreed@sjfc.edu dreed@sjfc.edu
} 


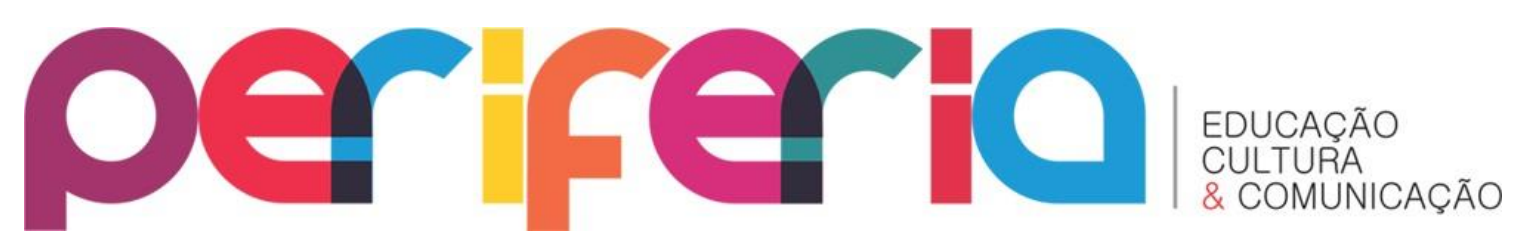

\section{LÍDERES EDUCACIONAIS RESILIENTES EM TEMPOS TURBULENTOS: APLICANDO O PERFIL DE RESILIÊNCIA DA LÍDER ® PARA AVALIAR A RESILIÊNCIA NO RELACIONAMENTO COM O GÊNERO E IDADE}

\section{Resumo}

Mulheres líderes em todo o mundo enfrentam um desafio comum: tempos extremamente turbulentos, que desafiam até mesmo as/os líderes mais habilidosas(os). 0 artigo começa com uma breve visão geral do significado da resiliência da(o) líder e descreve o ciclo de resiliência que todas(os) as/os líderes experimentam quando ocorrem as adversidades. São cinco as fases do ciclo de resiliência discutidas: condições normais, fase de deterioração, fase de adaptação, fase de recuperação e fase de crescimento. Em seguida, o artigo traça o desenvolvimento dos dados revisados do Leader Resilience Profile ${ }^{\circledR}$ (LRP) que comparam e contrastam a resiliência da(o) líder por gênero e idade. Os resultados mostram claramente que a resiliência aumenta de forma confiável com a idade. Os participantes na faixa etária acima de 60 anos, em comparação com todas as outras faixas etárias combinadas, tiveram escores de resiliência significativamente mais altos. Na faixa etária de 20 a 29 anos, os homens apresentavam uma resistência mais alta do que as mulheres. Não houve diferenças de gênero confiáveis na resiliência nas outras categorias de idade. Os resultados são baseados em uma amostra relativamente pequena. Pesquisas adicionais devem ser conduzidas em amostras maiores em cada faixa etária. 0 artigo conclui abordando duas questões: Como a LRP pode ser usada em todos os países para avaliar a resiliência das mulheres líderes e como a LRP pode ser aplicada para desenvolver oportunidades de crescimento profissional para fortalecer a resiliência das mulheres líderes.

Palavras-chave: líderes educacionais; resiliência; gênero; idade 


\section{periferio}

Educational leaders throughout the world confront challenges that test even the most skillful and experienced leaders. Increased levels of accountability, mandated implementation of common core learning standards and shrinking funds for public schools have created unique challenges for leaders seeking to increase student achievement levels and get students college or career ready. The twenty-first century leader works in complex environments that include more specialized services with increasing levels of federal and state mandates. The role of the leader requires high levels of energy and expertise during a time when there is increased political pressure in response to the economic recession. Also, there is instant world-wide media coverage and scrutiny of the decision making of leaders while the public demands transparency. In the face of adversity, some leaders succumb to the pressures involved, losing credibility and even their jobs. Their physical and /or emotional health is often affected. However, other leaders under comparable circumstances not only recover but grow stronger when confronted by adversity. They view challenges as opportunities and have a "can do it" attitude. They demonstrate leader resilience.

The purpose of this paper is to contribute to the research and conceptual understanding of leader resilience, in relation to gender and age, with a particular focus on the implications for women's professional development, globally. This paper presents original findings in regard to the LRP-R results on resiliency differences in relationship to gender and age. The paper begins with a brief overview of the meaning of leader resilience and describes the resilience cycle that all leaders experience when adversity strikes.

Next, the authors trace the development of the Leader Resilience Profile ® (LRP-R), a valid, reliable instrument that Dr. Diane Reed and Dr. Evan Blaine developed so leaders can assess their relative resilience strengths in nine areas. The book "Resilient Leadership for Turbulent Times: a guide to thriving in the face of adversity" by Dr. Diane Reed and Dr. Jerry Patterson was published in December 2009 by the American Association of School Administrators (AASA) and Roman and Littlefield. The paper highlights results from LRP-R data that 


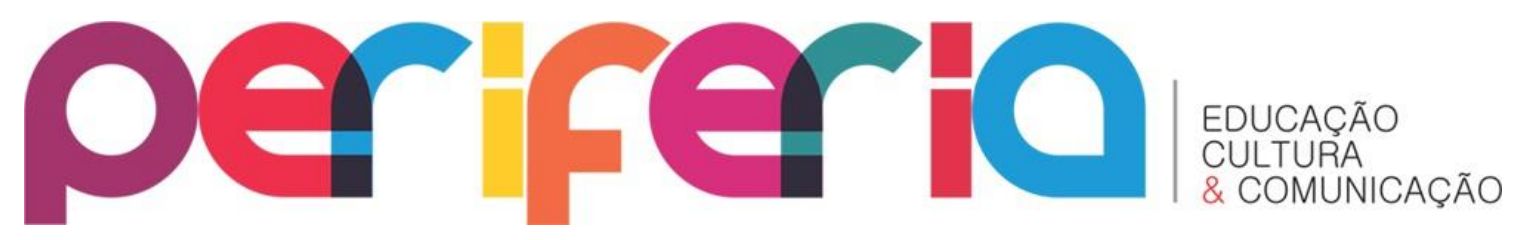

compares and contrasts leader resilience by gender and age. It provides leaders with concrete, 'how to' strategies for strengthening their leadership skills in the face of adversity and addresses specific needs and skills required to help leaders be successful in tough times. The paper concludes by addressing two issues: How the LRP-R can be used across countries to assess women leader resilience and how can the LRP-R be applied to develop professional growth opportunities to strengthen women leaders' resilience.

\section{WHAT IS RESILIENCE?}

Applying the concept of resilience to the world of education leadership, Patterson and colleagues have spent the past decade describing and researching leader resilience. We have authored Resilient Leadership for Turbulent Times (Patterson, Goens, and Reed, 2009). We define a resilient leader as one who demonstrates the ability to recover, learn from, and developmentally mature when confronted by chronic or crisis adversity. Warren Bennis, the recognized authority on organizational leadership, said resilience is the cornerstone to successful leadership. In the January 2007 issue of American Psychologist, Bennis wrote: 'I believe adaptive capacity or resilience is the single most important quality in a leader, or in anyone else for that matter, who hopes to lead a healthy meaningful life" (Bennis, 2007).

Resilience does not fluctuate on a daily or weekly basis. Instead, resilience reflects a pattern of how leaders view their current reality and how they assess the probability for influencing the future.

In our research we identified five phases of the resilience cycle 


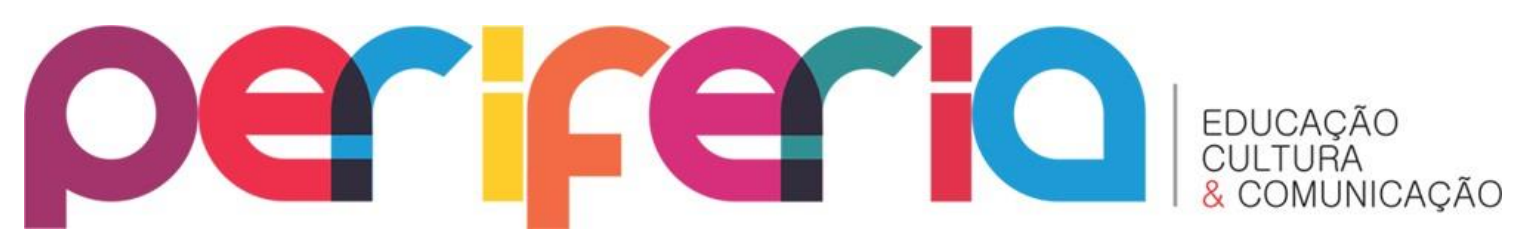

Figure 1 The Resillence Cycle

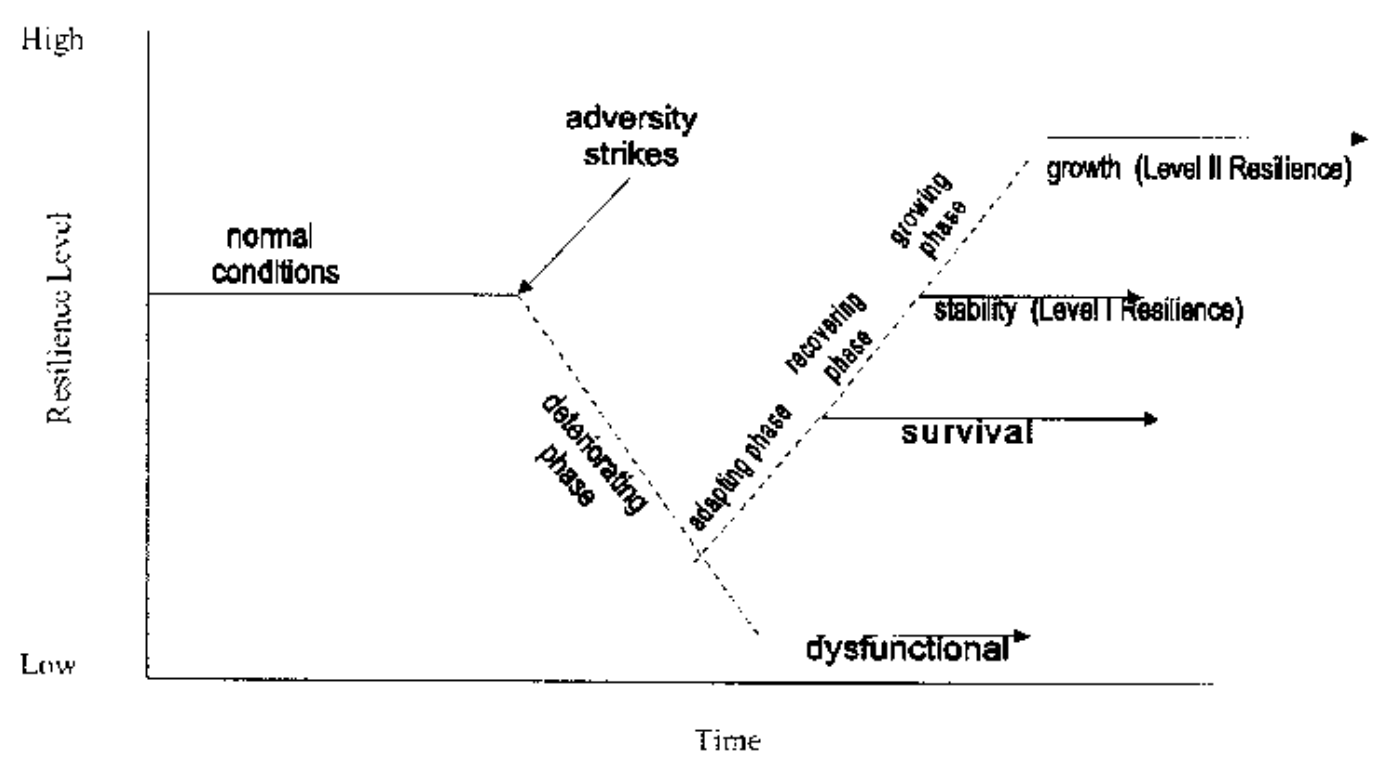

The cycle, illustrated in Figure 1, begins with the phase called normal conditions. This is where the organization is functioning routinely. Resources are plentiful, performance is high and there is ample community support. Then adversity strikes. For instance, dramatic school shootings pit various constituencies against each other, with protection of self-interests as the dominant motive in the battle. Often, we as leaders become both the target and an outlet for others' frustrations. We abruptly find ourselves in phase two, the deteriorating phase of the resilience cycle. This is where we think and act in ways that cause our stress to become more intense. We become angry and aggressive. We blame others. We become our own worst enemy. The emotions of denial, grief and anger thrust us into a reactive role. In short, we wallow in the victim status for a period of time. A distinguishing difference between resilient and non-resilient leaders is the time spent in phase two. As resilient leaders, we do not languish in the role of victim. We move on to phase three, the adapting phase. This begins when we assume some responsibility for our condition and take action to avoid staying stuck at the dysfunctional level of the resilience cycle. Continuing an upward trajectory, the adapting phase gives way to the recovering phase, a path back to the level of stability experienced 


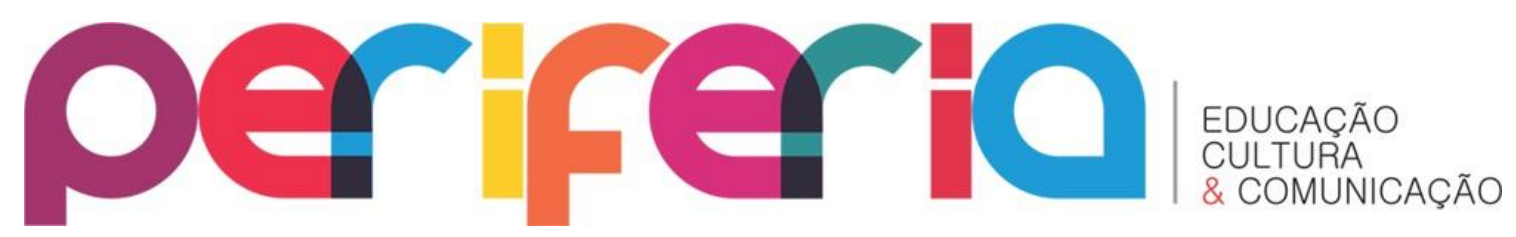

before the onset of adversity. We refer to this status quo point as Level I resilience. This is where we apply concrete strategies, outlined later, to help us recover. If we plateau at the status quo level, we may continue to function adequately but we do not experience growth from the lessons adversity can teach us. Truly resilient leaders do not settle for the status quo. We enter the growing phase on our way to strengthened resilience, Level II. Third (and this is the kicker), you choose whether to exercise the option. Below we outline three skill sets that successful leaders act on to help them become more resilient. We define a resilient leader as a person who demonstrates the ability to recover, learn from and grow stronger in the face of adversity.

Table 1 -

\begin{tabular}{|c|}
\hline Leader Resilience Skills \\
\hline Thinking Skills \\
Understanding Reality \\
Optimistic About the Future \\
\hline Capacity Skills \\
Personal: \\
Values $\quad$ Wficacy Support Base \\
Well-Being \\
Courageous Decision Making \\
Perseverance Responsibility \\
Adaptability
\end{tabular}

\section{Skill Set One: Resilient Thinking Skills}

Resilient leaders demonstrate optimistic thinking at two levels. They want to know about what is happening right now, and the good, the bad and the ugly. At another level, resilient leaders are realistic optimists as they envision future possibilities. They demonstrate the ability to maintain a 


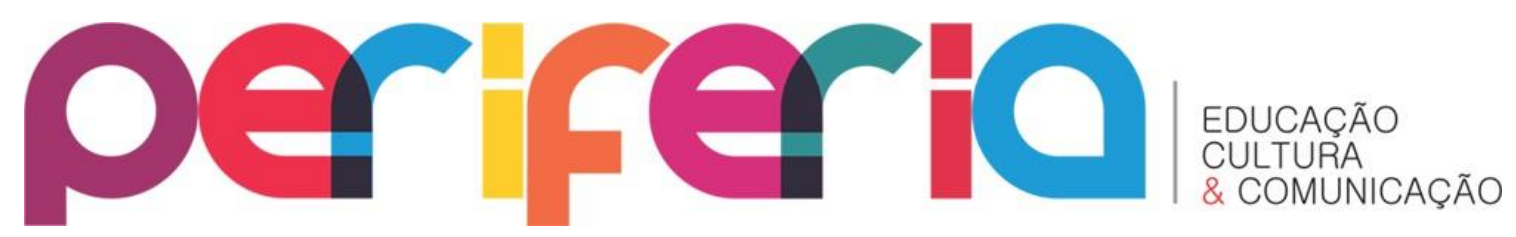

positive outlook about the future when tough times hit. Resilient leaders engage in resilient thinking when they ask themselves:

- How can I take steps to understand reality from as many different perspectives as possible?

- What do I need to do to find the positive aspects of adversity to offset the negative ones?

- How can I stay vigilant to focus my energy on future opportunities, not the obstacles, when I get slammed by crisis or chronic adversity?

\section{Skill Set Two: Resilience Capacity-Building Skills}

Resilience capacity is the amount of fuel you have in your resilience tank when storms strike. You can successfully expand your capacity when you reflect on these questions:

- What leadership actions do I need to take that are consistent with what matters most to me among competing values and in the face of strong opposition?

- What do I need to do to demonstrate a sense of confidence and competence, as well as a respected leadership presence, in the midst of crisis?

- How can I identify others I can trust to talk frankly to about my doubts and fears when the going gets rough?

\section{Skill Set Three: Resilience Action Skills}

As stated there are three skill sets required for resilient leadership. The first two sets we discussed are necessary, but not sufficient, to sustain your resilience. The third set, resilience action skills, is crucial to carry out the demonstrated abilities that we refer to in skill sets one and two. In other 


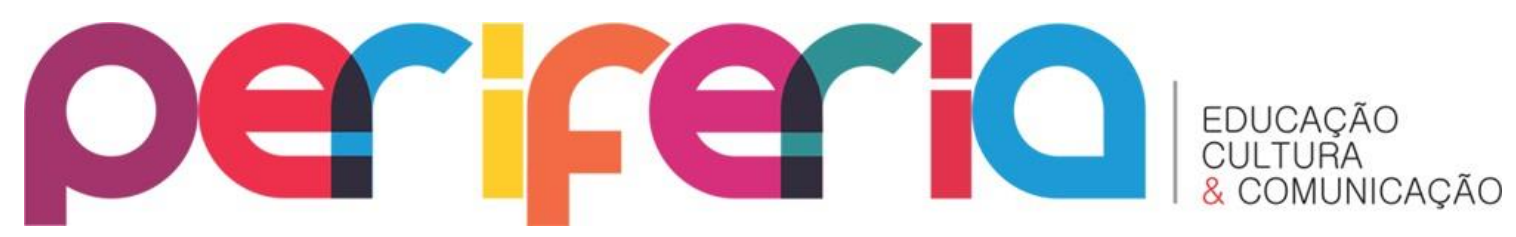

words, unless you act on the courage of your convictions, everything else is just talk.

Four action skills are necessary to strengthen your leader resilience; perseverance, adaptability, courageous decision-making and personal responsibility. Below are questions to consider as you strengthen your action skills.

- What do I have to do to remain persistent and focused through tough times until I succeed in achieving my goal?

- What will it take for me to become more adaptable by putting my mistakes in perspective and moving beyond them?

- How can I find the courage to act in concert with my convictions, particularly when I am faced with extreme pressure by opposing forces?

- What do I need to do to demonstrate to others that I stand accountable for the long-term organizational impact of any tough leadership decisions I make?

\section{DEVELOPING THE ORIGINAL LEADER RESILIENCE PROFILE}

The purpose of the LRP is to provide leaders with an individualized profile of their resilience. After careful analysis of the results, we identified subscales, summarized below, along with descriptors that elaborate each subscale.

\section{Strength 1: Understanding of Reality and Optimism}

Resilient leaders demonstrate the ability to understand, from as many diverse perspectives a possible, the reality of what is happening when the organization is hit with adversity. Resilient leaders demonstrate the ability to maintain a positive outlook about the future, without denying the obstacles posed by reality. 


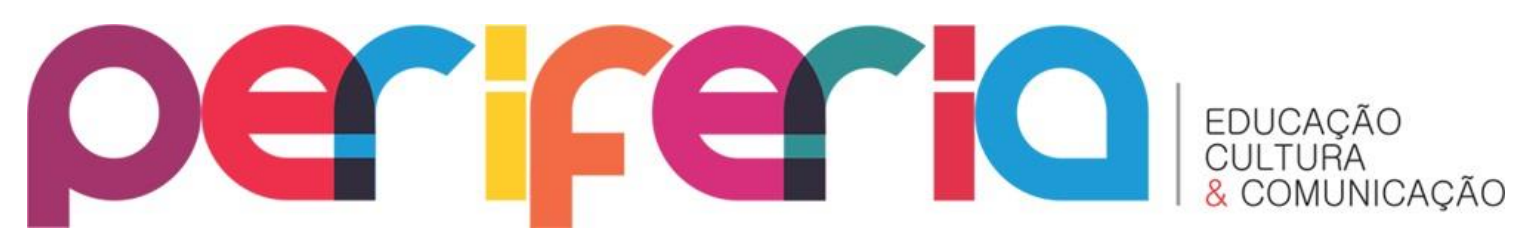

Strength 2: Values

Resilient leaders demonstrate the ability to align their leadership actions with their values about what matters most.

\section{Strength 3: Efficacy}

Resilient leaders demonstrate the ability to maintain confidence and their competence to lead in the thick of adversity.

\section{Strength 4: Well Being}

Resilient leaders demonstrate the ability to maintain their emotional, physical, and spiritual health when adversity strikes.

\section{Strength 5: Support Base}

Resilient leaders demonstrate the ability to draw upon a strong support base to help them through adversity.

\section{Strength 6: Courageous Decision Making}

Resilient leaders demonstrate the ability to consistently act on the courage of their convictions when faced with adversity.

\section{Strength 7: Perseverance}

Resilient leaders demonstrate the ability to stay the course and succeed, not letting diversity get the best of them. 


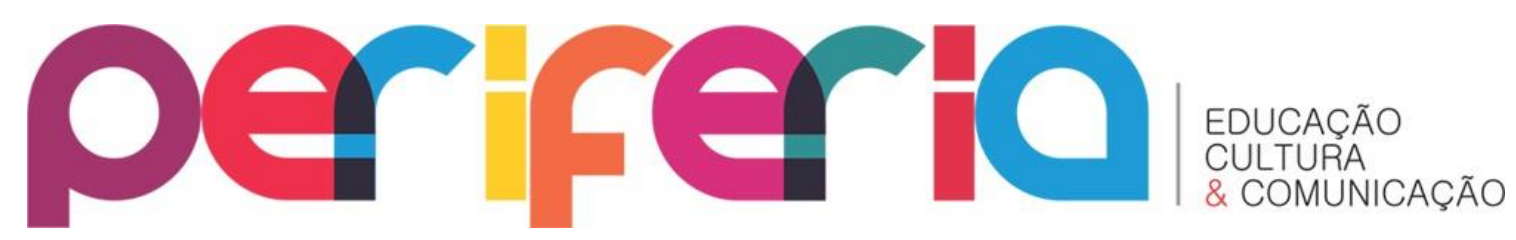

Strength 8: Personal Responsibility

Resilient leaders demonstrate the ability to accept personal responsibility for their leadership actions in difficult circumstances.

\section{Strength 9: Adaptability}

Resilient leaders demonstrate the ability to apply flexible, creative approaches to successfully navigate through obstacles posed by adversity.

\section{METHOD}

This investigation had IRB approval from the University and the LRP-R instrument has been copyrighted and can only be used with the permission of the authors. Consent was obtained from the people involved in the study and anonymity was guaranteed. The data has been used only for the purpose of this article.

The original Leadership Resilience Profile (Patterson, Goens, \& Reed, 2009) was revised in 2012 to shorten the instrument and improve its psychometric properties. The revised instrument (LRP-R) consists of 11 fouritem subscales measuring the resilience dimensions described earlier, and has been validated in prior research (Reed \& Blaine, 2015). The data in the present study were collected through the senior author's consulting work and from respondents through the LRP-R's website (http://theresilientleader.com/quiz/index.php). Overall resilience scores were calculated by averaging the 11 subscale scores for each participant; overall scores could range from 5 (lowest resilience) - 20 (highest resilience). The overall scale demonstrated adequate internal consistency in this sample $($ Cronbach's alpha $=.74)$. LRP-R subscale scores were not the focus of this study. 


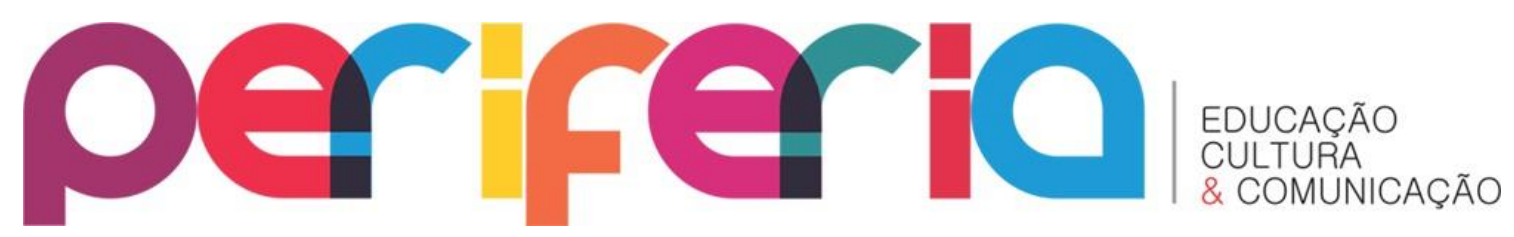

\section{RESULTS}

LRP-R responses from 277 participants (female $n=181,65 \%$; male $n=96$, $35 \%$ ) were explored for gender differences in resilience and in the relationships between gender, resilience, and age. Female $(M=16.4, S D=1.7)$ and male $(M=16.9, S D=1.8)$ participants did not significantly differ in overall resilience. $A$ 1 -way ANOVA of resilience scores by age category found that resilience increased reliably with age, although the magnitude of the relationship was small, $F(4,270)=3.11, p=.016$, eta squared $=.04$. The descriptive statistics appear in Table 1.

Table 1. Sample Characteristics by Age Group

\begin{tabular}{lllll}
\hline & & & \multicolumn{2}{c}{ LRP-R Resilience } \\
\hline Age & N & Female N (\%) & Mean & SD \\
\hline $\mathbf{2 0 - 2 9}$ & 69 & $47(68 \%)$ & 16.1 & 2.1 \\
\hline $\mathbf{3 0 - 3 9}$ & 69 & $40(58 \%)$ & 16.4 & 1.3 \\
\hline $\mathbf{4 0 - 4 9}$ & 64 & $41(64 \%)$ & 16.7 & 1.8 \\
\hline $\mathbf{5 0 - 5 9}$ & 46 & $33(72 \%)$ & 16.8 & 1.3 \\
\hline$\geq 60$ & 27 & $18(67 \%)$ & 17.4 & 1.8
\end{tabular}

Source: from the author (2018).

A planned contrast showed that participants in the 60+ age group, compared with the all other age groups combined, had significantly higher resilience scores, $F(1,270)=6.82, p=.009$. To explore the influence of gender in this relationship, the boxplots in Figure 1 show resilience scores separately by age group and gender. The general increasing trend noted above is more clearly seen among females than males, suggesting that the relationship between age and resilience differ for female and male participants. To explore this, Wilcoxon rank-sum tests were conducted to test the difference between male and female median resilience in each age group, correcting the $p$ values by the Bonferroni method for the set of tests. The results of those tests revealed that in the 20-29 age group, men ( $N=22$, median=17.3) had significantly higher 


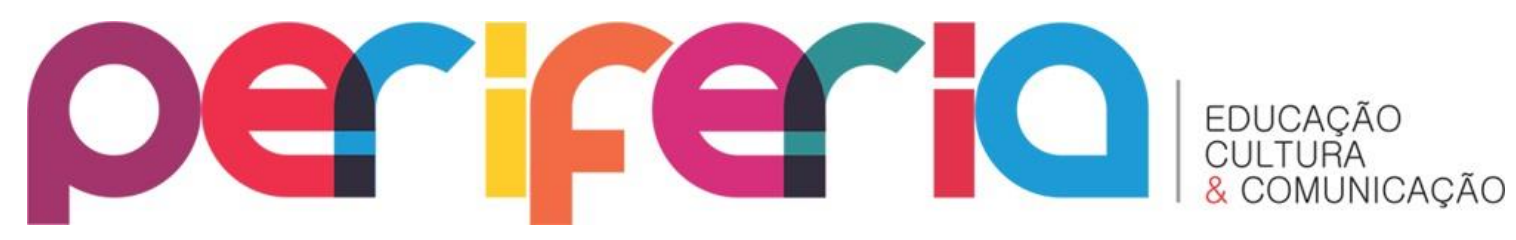

resilience than women $(\mathrm{N}=47$, median=15.6), Wilcoxon $\mathrm{W}=215.5, \mathrm{p}=.0001$. There were no reliable gender differences in resilience in the other age categories.

Figure 2. LRP-R Resilience by Gender and Age

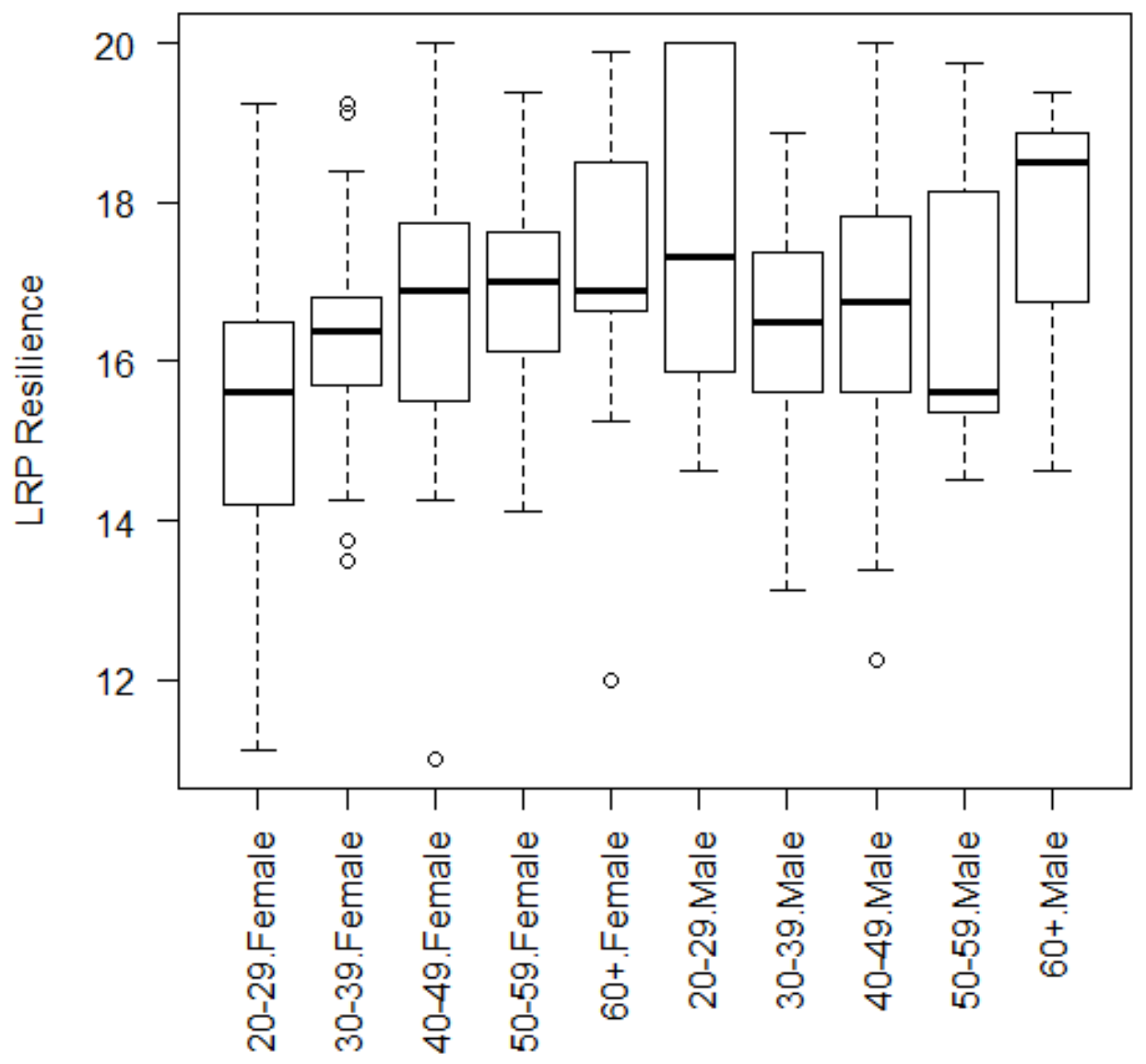

Source: from de author (2018).

\section{RECOMMENDATIONS}

You can expand your own understanding and skills related to leader resilience by taking the following actions: Read the book Resilient Leadership for Turbulent Times to learn more in-depth the strategies that resilient leaders practice. In the book, we expand on the skill sets described in this paper to 


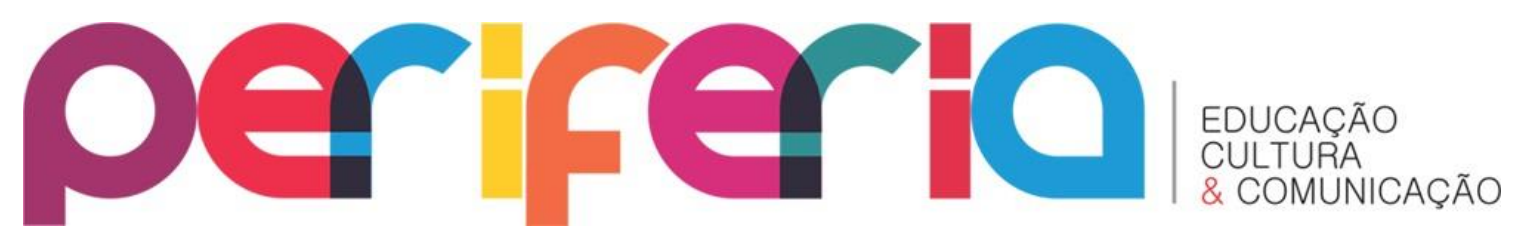

help you develop concrete strategies to build your leader resilience. Complete the Revised Leader Resilience Profile online at www.theresilientleader.com. There is no cost to do this. This provides you a customized profile of your resilience strengths. Then develop an action plan for becoming more resilient. If you take these steps you are on your way to providing a foundation to answer the questions we have posed. In this paper, we have described our recent research in both conceptualizing and assessing leader resilience. Based on our work to date, we have documented the importance that women leaders place on leader resilience in turbulent times. Drawing from our book on leader resilience (Patterson, Goens, and Reed, 2009), we have constructed a four-part series for leader resilience training as described below that you can follow to strengthen your own resiliency as you age.

The first program is an overview of leader resilience. Participants will develop a comprehensive understanding of the 'big picture' of leadership resilience. The second program is an in-depth examination of resilience thinking skills. Participants will learn how to apply the thinking skills of $a$ realistic optimist. The third program is an in-depth examination of resilience capacity building skills. Participants will learn how to build additional resilience capacity in four areas: personal values, personal efficacy, personal well-being and personal support base. The fourth program in an in-depth examination of resilience action skills. Participants will learn how to strengthen their leadership skills of adaptability, perseverance, courage, and personal accountability. A simulation of real-life situations will be used to gain experience in leading in the heat of a crisis. Leaders begin with Program One and then can select any other combinations of programs they feel will fit their needs. We invite women leaders across the globe to capitalize on their collective wisdom and experience to identify ways to make available leader resilience training for women leaders internationally.

As Helen C. Sobehart (2009) framed the challenge for women leaders, "An issue better understood makes us better able to make a strategic impact on the condition of the underrepresented and underserved (p.218). Applying this challenge to the issue of women leaders' resilience, we propose a future Periferia, v. 10, n. 2, p. 119-134, jul./dez. 2018 


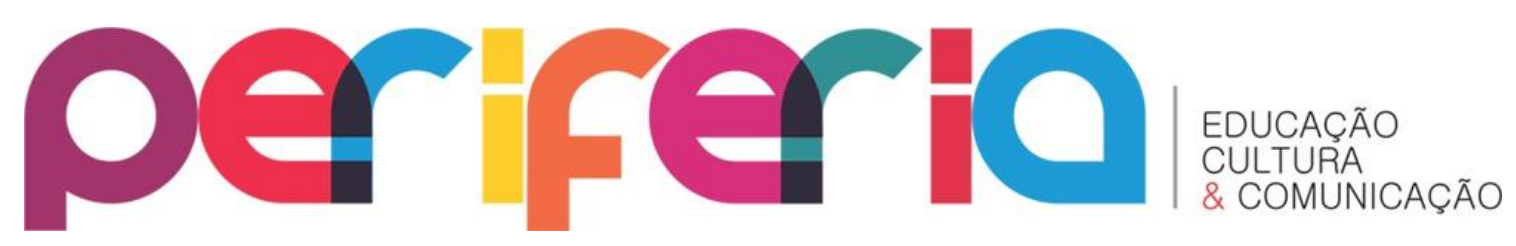

research agenda that adapts Sobehart's ideas shared at the Women Leading Education across Continents Conferences in Rome (2007), Augsburg, Germany (2009) and Volos, Greece (2011).

The following areas to be explored are:

- the status of women in educational leadership across continents in the area of leader resilience;

- how the lived experiences of conference participants have influenced their leader resilience;

- how women navigate cultural constraints in order to become more resilient leaders;

- how we can provide inspiration and access to aspiring and newly appointed women leaders, and support them in their efforts to recover, learn from, and grown stronger in the face of adversity.

\section{CONCLUSION}

This paper highlights results from the LRP-R data that compares and contrasts leader resilience by gender and age. The results clearly show that resilience increases with age. In the 20-29 age group men had significantly higher resilience than women. However, there was no gender differences in resilience in the other age categories. The findings are based on a relatively small sample. Further research should be conducted on larger samples in each age range. The paper concludes by addressing two issues: how can the LRP be used across countries to assess women leader resiliency as they age and how can the LRP-R be applied to develop professional growth opportunities to strengthen women leaders' resilience. 


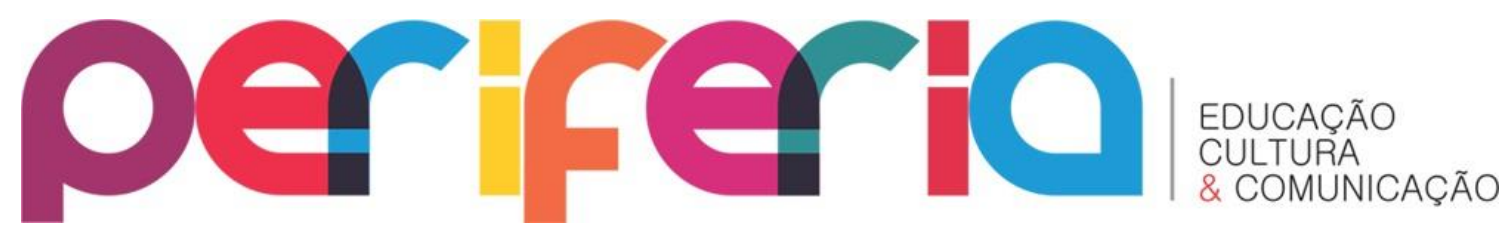

\section{REFERENCES}

BENNIS, W. The challenges of leadership in the modern world: Introduction to the special issue. American Psychologist, v.62, n.1, p. 5, 2007

BLOCK, J.; KREMEN, A. IQ and ego resiliency: Conceptual and empirical connections and separateness. Journal of Personality and Social Psychology, n. 70, p. 349-361, 1996

CHRISTMAN, D.; MCCLELLAN, R. Living on barbed wire: Resilient women administrators in educational leadership programs. Paper presented at the annual American Educational Research Association conference, Montreal, Canada, April 2005.

FROHMAN, D. Leadership under fire. Harvard Business Review, p. 124-131, Dec. 2007

HOWE, N.; STRAUSS, W. Millennials rising: The next great generation. New York: Random House, 2000.

LOEHR, J.; SCHWARTZ, T. The power of full engagement: Managing energy, not time is the key to high performance and personal renewal. New York, NY: Free Press, 2003.

PANKAKE, A.M.; BEATTY, D. Stories of resiliency: Successful female educational leaders. Journal of Women in Educational Leadership, v.3, n. 3, p. 175-191, 2005.

PATTERSON, J.; GOENS, G.; REED, D. Resilient leadership for turbulent times, Lanham, MD, USA: Rowman and Littlefield Education, 2009.

PATTERSON, J.; KELLEHER, P. Resilient school leaders: Strategies for turning adversity into achievement. Alexandria: Association for Supervision \& Curriculum Development, 2005.

PATTERSON, J.; PATTERSON, J.; COLLINS, L. Bouncing back! How your school can succeed in the face of adversity. Larchmont, NY: Eye on Education, 2002.

REED, D.; PATTERSON, J. Voices of resilience from successful female superintendents. Journal of Women in Educational Leadership, v. 5, n.2, p. 89100, 2007.

SMITH, B.; DALEN, J.; WIGGINS, K.; TOOLEY, E.; CHRISTOPHER, P.; BERNARD, $J$. The Brief Resilience Scale: Assessing the ability to bounce back. International Journal of Behavioral Medicine, n.15, p. 194-200, 2008. 


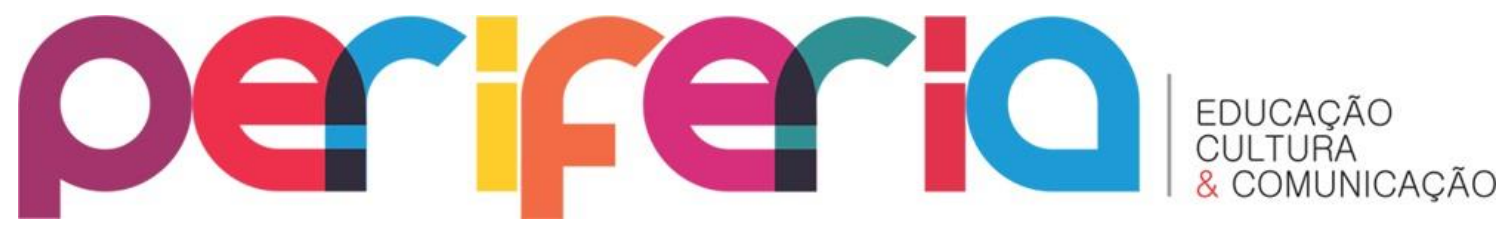

SOBEHART, H. C. (ed.). Women leading education across the continents: Sharing the spirit, fanning the flame. New York, NY: Rowman \& Littlefield Education, 2009. 